\title{
Nasalização heterossilábica de [a] no português de São Tomé e Príncipe
}

\section{Heterosyllabic Nasalization of [a] in São Tomé and Príncipe Portuguese}

Amanda Macedo Balduino [amanda.m_b@hotmail.com]

Universidade de São Paulo, Brasil

Gabriel Antunes de Araujo [gabrielaraujo@um.edu.mo]

澳门大学, University of Macau, China

Universidade de São Paulo, Brasil

Ana Lívia Agostinho [a.agostinho@ufsc.br]

Universidade Federal de Santa Catarina, Brasil

MANuele BANDeira [manuelebandeira@unilab.edu.br]

Universidade da Integração Internacional da Lusofonia Afro-Brasileira, Brasil

\section{RESUMO}

O objetivo deste artigo é descrever e analisar o processo de nasalização heterossilábica da vogal baixa [a] nas variedades de português faladas em São Tomé e Príncipe (STP): o português vernacular santomense e o português vernacular principense. STP é um país multilíngue onde, além do português, são faladas línguas crioulas, dentre as quais o santome e o lung'Ie. Com base em uma abordagem metodológica experimental, realizamos análises acústicas e perceptuais que abarcaram a mensuração da duração dos segmentos sob análise, assim como a mensuração dos formantes que os compunham. Esse exame foi acompanhado por uma análise fonológica que considerou aspectos como acento e formação do pé dos itens nos quais a nasalização heterossilábica foi implementada. Os resultados indicam que a nasalização heterossilábica é opcional para a vogal baixa em posição tônica, demarcando uma diferença em relação ao português europeu e brasileiro, variedades nas quais esse processo é obrigatório em contextos similares. Este resultado demonstra uma aproximação em relação às línguas autóctones e caracterizam as variedades estudadas como singulares.

\section{Palavras-Chave}

Nasalidade; Sílaba; Fonologia; Português de São Tomé; Português de Príncipe. 


\begin{abstract}
This study describes and analyzes the low vowel [a] heterosyllabic nasalization processes in two Portuguese varieties spoken in São Tomé and Príncipe (STP): the Santomean vernacular Portuguese and the Principense vernacular Portuguese. STP is a multilingual country where, in addition to Portuguese, creole languages are spoken, including Santome and Lung'le. Based on an experimental methodological approach, we performed acoustic and perceptual analyses that included measuring the duration of the segments under analysis and the formants that comprised them. In addition, this research contains a phonological study that considers primary stress and formation of foot in which heterosyllabic nasalization occurs. The results indicate that heterosyllabic nasalization is optional for the low vowel in a stressed position, marking a difference concerning European and Brazilian Portuguese, varieties in which this process is mandatory in similar contexts. These results suggest an approximation to the native languages and characterize the studied varieties as distinct.
\end{abstract}

\title{
KEYWORDS
}

Nasality; Syllable; Phonology; São Tomé Portuguese; Principense Portuguese.

RECEBIDO 2020-18-09; ACEITE 2021-02-03

Agradecimentos: Amanda Macedo Balduino agradece à FAPESP (15/25332-1) pelo financiamento. Gabriel Antunes de Araujo agradece à Universidade de Macau (bolsa SRG-2019-00153-FAH), ao Conselho Nacional de Desenvolvimento Científico e Tecnológico (CNPq), pela bolsa de produtividade no 310463/2016-5 e à Universidade de São Paulo. Ana Lívia Agostinho e Manuele Bandeira agradecem ao CNPq, processo: 200519/2019-0 e processo: 150051/2018-2, respectivamente.

\section{Introdução}

A República Democrática de São Tomé e Príncipe (STP) é um país multilíngue localizado no Golfo da Guiné, na costa oeste africana. Em STP, além do português, língua oficial do arquipélago desde 1975, são faladas o santome (código ISO 639-3: cri), o angolar (ISO 639-3: aoa), o kabuverdianu (ISO 639-3: kea) e o lung'Ie (ISO 639-3: pre), línguas crioulas formadas a partir do contato linguístico entre o português e línguas africanas. De acordo com o censo demográfico de 2012 (INE, 2012), o português é falado por 98,4\% da população, 36,2\% declaram também falar o santome, $6,6 \%$ o angolar e $1 \%$ o lung'Ie. ${ }^{1}$ Os números de falantes das línguas nacionais, quando comparados aos do português, indica o declínio das línguas autóctones, marcado, principalmente, pela falta de transmissão intergeracional dessas línguas (Agostinho 2015: 348; Araujo 2020; Gonçalves 2010).

Este estudo tem como propósito descrever e analisar o processo de nasalização heterossilábica na vogal baixa [a] em duas variedades urbanas da língua portuguesa em STP: o português vernacular santomense (PST), falado na capital São Tomé, e o português vernacular principense (PP), empregado na cidade de Santo António, na Ilha do Príncipe. A distinção entre tais variedades é interessante porque, além da distância geográfica existente entre elas, o PST e o PP apresentam ecologias linguísticas singulares e estão em diferentes situações de contato linguístico. Adicionalmente, podemos

1 Nos dados do Censo, não fica estabelecido o percentual para os falantes de kabuverdianu, tendo sido essa língua incluída no grupo 'outras línguas' (INE, 2012). 
ampliar o espaço linguístico da língua portuguesa, tratando o PST e o PP como conectados ao português falado em outros lugares (Bonvini 2008: 21), contrastando os resultados obtidos com estudos congêneres dedicados ao português do Brasil (PB) e ao português de Portugal (PE). ${ }^{2}$

O processo de nasalização, a partir do onset silábico, é comumente denominado na literatura como nasalidade alofônica (Câmara Jr. 1970; Moraes e Wetzels 1992) ou temporária (Miguel 2006). Nas variedades brasileira (Câmara Jr. 1970) e europeia (Mateus e D’Andrade 2000), o processo pode ser obrigatório ou opcional, a depender de alguns fatores linguísticos, como o contexto acentual, a direcionalidade e a classe da palavra, ou até mesmo extralinguísticos, como a região em que a variedade do português é falada (Wetzels 1997).

Neste trabalho, o processo de nasalização regressiva a partir de onset nasal, no PST e no PP, será denominado 'nasalidade heterossilábica', uma vez que ocorre a partir do espraiamento do traço nasal de onset para a vogal da sílaba anterior, portanto, em uma sílaba diversa daquela na qual está a fonte da nasalidade. Assim, não adotaremos a mesma terminologia empregada para o PB e para o PE, pois esta não se mostra adequada ao comportamento do fenômeno em questão nas variedades de STP. ${ }^{3}$

A fim de distinguir os dois tipos de nasalidade, representaremos, portanto, o processo de nasalização heterossilábica como ( $\tilde{V} . \mathrm{N})$ no qual as vogais nasalizadas adquirem o traço de nasalidade por meio de uma fonte fora de sua sílaba, e o processo de nasalização tautossilábica como (ṼN), no qual a vogal sofre a nasalização na mesma sílaba.

Doravante, $\mathrm{V}$ representa uma vogal oral, $\tilde{\mathrm{V}}$ uma vogal nasalizada, $\mathrm{N}$ uma consoante nasal, $\mathrm{C}$ uma consoante, (.) a fronteira silábica e ['], o acento primário. Assim como a língua portuguesa, duas línguas autóctones de STP, o santome (ST) e o lung'Ie (LI), também apresentam processos de nasalização. Agostinho (2015), Agostinho, Balduino \& Araujo (2020) e Bandeira (2017) descrevem processos de nasalidade tautossilábica contrastiva no LI e no ST, respectivamente. Contudo, os autores sugerem também a existência de um segundo tipo de nasalização da sílaba anterior, a partir do espraiamento do traço de nasalidade de um onset nasal como [m] ou [n] para a vogal (Agostinho 2015: 115; Bandeira 2017: 348). Na nasalidade heterossilábica observada em tais línguas, o espraiamento do traço [nasal] ultrapassa a fronteira silábica, porém apenas os segmentos dentro da rima da sílaba adjacente são nasalizados (Araujo \& Balduino, 2019). Esse fenômeno é, portanto, regressivo, ocorrendo para a esquerda, e opcional, sendo identificado, no lung'Ie, em sílabas tônicas que antecedem uma consoante nasal no onset da próxima sílaba à direita, como indicado em (1.a) e (1.b) (Agostinho 2015: 111; Agostinho et al. 2020). ${ }^{4}$

(1) a. kama ['ka.me] ['kẽ.me] 'cama'

b. mano ['ma.nu] ['m̃̃.nu] 'irmão'

c. kana [ka'na] 'cana-de-açúcar' *[kẽe'na]

2 Além do PST e do PP, outras variedades da língua portuguesa têm sido descritas na literatura, como o português dos Tongas (Baxter 2002, 2018) e o português de Almoxarife (Figueiredo 2010, 2014).

3 Lao (2020) e Lao, Rodrigues e Bressos (2020) tratam esse processo como Nasalidade Regressiva Heterossilábica (NRH).

4 Agostinho \& Hyman (2021) apresentam uma análise tonal do lung'Ie, em que as sílabas proeminentes em (1) carregam um tom /H/ culminativo. Os autores argumentam que as sílabas com /H/ são proeminentes na língua, mesmo não considerando-as como acentuadas. 
De acordo com Agostinho (2015) e Agostinho et al. (2020), o acento é relevante para determinar a nasalidade heterossilábica no lung'le, uma vez que, em átonas, o fenômeno não é observado, como exemplificado em (1.c). No santome, de modo distinto, a nasalidade engatilhada por um onset nasal é verificada não somente em sílabas tônicas (2.a), mas também em átonas (2.b) (Bandeira 2017: 349).

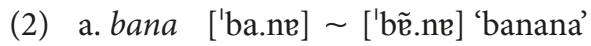

b. kama $[\mathrm{ka} . \mathrm{ma}] \sim[\mathrm{k \tilde {e }} . \mathrm{ma}]$ 'escamar'

A despeito das diferenças inerentes a cada língua, seja para o santome, seja para o lung'le, os dados em (1) e (2) indicam que o espalhamento heterossilábico da nasalidade em sílabas tônicas não é obrigatório como previsto para o PB e para o PE. Observamos, desse modo, que, afastando-se das variedades brasileira e europeia da língua portuguesa, a nasalização heterossilábica é totalmente opcional no santome e no lung'le. ${ }^{5}$

Considerando o contexto multilíngue e de contato entre as línguas em STP, investigamos se o processo de nasalização heterossilábica no PST e no PP pode ser, de algum modo, influenciado pelo contato linguístico. Para tanto, procuramos delinear se esse processo ocorre, no PST e no PP, de modo similar ao identificado no PE e no PB, se seguem os padrões das línguas autóctones ou se ainda demonstram um comportamento distinto. No que se refere ao processo de nasalização heterossilábica, também analisamos a possibilidade de aplicação do processo em $\mathrm{V}$ da primeira sílaba da sequência CV.'NV. Além disso, cientes da possibilidade de nasalização progressiva descrita por Agostinho (2015) para este contexto acentual, também examinamos, nas variedades do português de STP, a presença ou não da nasalização de $\mathrm{V}$ da sílaba tônica de itens lexicais com o padrão CV.'NV.

Este artigo está organizado do seguinte modo: na próxima seção, indicamos os métodos e os procedimentos adotados para a investigação do fenômeno. Em seguida, na seção Nasalização heterossilábica no PST e no PP, descrevemos e analisamos os dados. Para tanto, inicialmente, caracterizamos acusticamente o processo de nasalização vocálica e, posteriormente, interpretamos os resultados de acordo com uma perspectiva fonológica. As considerações finais são indicadas na seção final.

\section{Métodos e procedimentos}

O corpus utilizado neste texto é composto por dados de fala controlada abarcando 17 itens lexicais para o PST e para o PP coletados em STP em 2016. Esses itens lexicais foram organizados em dois diferentes grupos de dados que cumprem objetivos específicos na análise da nasalidade heterossilábica nas variedades aqui apresentadas. Desse modo, das palavras coletadas, temos: (i) um grupo

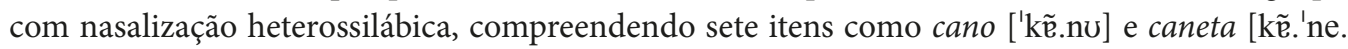
te] [ka.'ne.te] e (ii) um grupo de controle, o qual é formado por dez palavras (quatro pares mí-

5 O LI apresenta, ainda, a possibilidade de nasalidade progressiva engatilhada por um onset nasal, como indicado em exemplos: /bana/ [ba'na] [ba'ñ̃ ] 'banana', /kumi/ [ku'mi] [ku'mĩ] 'lugar, caminho', entre outros. Para uma discussão sobre a nasalidade no LI, ver Agostinho et al. (2020). 
nimos) com nasalidade tautossilábica, como canto ['kẽ.tu] e cato ['ka.tu]. Os dados do primeiro e do segundo grupos estão listados no quadro $1^{6}$. O item babu é um logatoma criado para completar o paradigma dos pares mínimos.

\begin{tabular}{|c|c|c|c|}
\hline \multicolumn{2}{|c|}{ Grupo I - Dados (CV.'NV e 'CV.NV) } & \multicolumn{2}{|c|}{ Grupo II - Controle } \\
\hline banana & 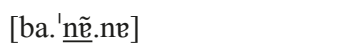 & babu $(L)$ & [ba.'bu] \\
\hline cama & ['kễ.me] & bambu & 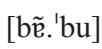 \\
\hline cano & 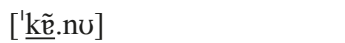 & cato & ['ka.tu] \\
\hline mana & 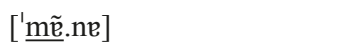 & canto & ['kẽe.tu] \\
\hline banana & 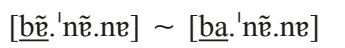 & mata & ['ma.te] \\
\hline camada & 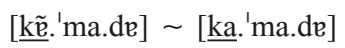 & manta & ['mẽ.te] \\
\hline \multirow[t]{4}{*}{ caneta } & 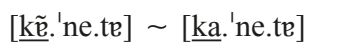 & nado & ['na.dv] \\
\hline & & nando & ['ñ̃.du] \\
\hline & & cancan & 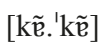 \\
\hline & & kaká & [ka.'ka] \\
\hline
\end{tabular}

Quadro 1: Itens Lexicais analisados: dados com nasalidade heterossilábica e grupo de controle.

Os itens lexicais coletados e organizados no grupo I apresentavam a sequência 'C[a].NV ou $\mathrm{C}[\mathrm{a}]$.'NV, ou seja, a vogal da sílaba inicial da palavra era sempre [a] seguida por uma consoante [m] ou [n]. A posição acentual da sílaba-alvo podia ser tônica ou pretônica, tendo sido coletados quatro itens em posição tônica e três itens em posição pretônica. A partir desse material, buscamos descrever e verificar a possibilidade e o comportamento da nasalização heterossilábica motivada pela consoante nasal no onset e pela proeminência acentual.

O grupo II, por seu turno, constitui o grupo de controle na medida em que proporciona o contraste entre os diferentes tipos de nasalidade no PST e no PP, isto é, a nasalização tautossilábica e a nasalização heterossilábica, bem como permite a comparação entre a vogal nasalizada e a vogal oral. A direcionalidade da propagação da nasalidade será descrita e examinada com base em itens dos dois grupos que contêm a consoante nasal em posição de onset no início da palavra, como ocorre, por exemplo, em mata ['ma.te].

Aqui, seguimos uma abordagem metodológica experimental (Albano 2017; Ohala 1995), portanto, os dados utilizados no experimento foram coletados por meio da gravação de palavras-alvo com falantes nativos em contextos controlados, no qual o item-alvo era inserido na frase-veículo Eu falo $x$ baixinho. Neste caso, $x$ era substituído pela estrutura-alvo. Durante a coleta de dados, a frase foi repetida três vezes pelo mesmo informante, em uma sequência aleatória. Para

6 As transcrições do quadro 1 foram realizadas tendo em vista o comportamento previsto no PB e no PE para, posteriormente, serem comparados com os dados do PST e do PP. Ainda no quadro 1, o item banana está repetido, pois

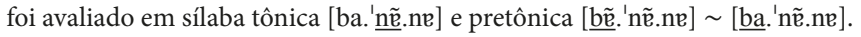


a análise, foi descartada a primeira produção. Portanto, apenas as duas repetições posteriores foram analisadas, totalizando, 28 ocorrências por informante. O material foi gravado em formato WAV com um gravador digital zoom H4n e microfone AKG C 520 L. No total, foram gravados 10 informantes em situação de fala controlada, sendo cinco informantes falantes do PST e cinco do PP. Todos os informantes tinham o português como língua materna, contudo o domínio das línguas santome ou do lung'Ie foi desconsiderado.?

A análise acústica desse corpus seguiu duas etapas: (i) a mensuração da duração das estruturas -alvo e a análise perceptual e acústica dos itens lexicais; (ii) a mensuração dos formantes das estruturas-alvo. Na primeira etapa, foram extraídas a duração dos itens lexicais-alvo, com o auxílio das ferramentas do programa Praat (Boersma e Weenick 2015). Assim, dentro de uma sequência 'CV.NV e CV.'NV, selecionamos V ou Ṽ.N (a depender da aplicação ou não do processo) da primeira sílaba e extraímos sua duração em milissegundos, seguindo a metodologia de Moraes e Wetzels (1992). Sabendo disso, a duração dos segmentos nasalizados, bem como o exame da presença e/ou ausência do apêndice nasal são relevantes, pois, podem nos dar pistas acerca da origem do fenômeno de nasalidade em questão, demonstrando se esta possui natureza distinta da nasalidade tautossilábica e se a articulação é um fator relevante para ambos os processos nas variedades estudadas.

O último parâmetro acústico de análise das vogais nasalizadas foi a extração dos valores dos três formantes iniciais (F1, F2 e F3), a partir da porção medial do segmento-alvo. De acordo com Medeiros (2007) e Souza e Pacheco (2012), um dos aspectos que indicam o contraste entre as

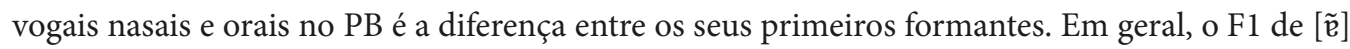
é 100-200 Hz menor que o valor de [a] (Medeiros 2007: 173). Adicionalmente, a média desse componente acústico é a mesma tanto para as vogais nasais tautossilábicas, quanto para as vogais nasalizadas (Souza e Pacheco 2012: 419). Assim, de modo a comprovar a ocorrência ou não da nasalidade nas vogais-alvo no PST e no PP, as médias de F1 foram contrapostas aos resultados obtidos para as vogais nasalizadas, com os valores retirados para as vogais nasais e orais.

Nos valemos do segundo grupo de dados formados por pares mínimos que contivessem a oposição nasal $x$ oral, e cuja consoante $C_{1}$ nas sequências [' $\left.C_{1} V . N V\right]$ ou $\left[C_{1} V . ' N V\right]$, correspondesse à mesma consoante que antecedia a vogal-alvo deste estudo, tanto para a contraposição da duração das vogais nasais e orais com a duração das vogais nasalizadas, quanto para a comparação dos valores de F1. As comparações realizadas foram organizadas conforme o quadro 2.

\footnotetext{
7 A despeito de o contato linguístico constituir um dos fatores que podem exercer alterações estruturais na nasalidade do PST e do PP, o domínio das línguas crioulas é muito heterogêneo entre os informantes participantes do estudo. Enquanto dois informantes afirmam falar o lung'ie e o santome como línguas maternas, os demais falantes relataram acessos e domínios distintos das línguas crioulas faladas em STP. A heterogeneidade no domínio das línguas crioulas reflete a atual situação sociolinguística do arquipélago, uma vez que o português tem ascendido a uma posição hegemônica, em detrimento das línguas locais que, desprovidas de políticas linguísticas destinadas à sua preservação e documentação, têm sido cada vez menos transmitidas intergeracionalmente (cf. Araujo 2020). Neste estudo, como a variável "domínio das demais línguas locais" não pôde ser mensurada, não a avaliaremos. Entretanto, ressaltamos a importância de, ainda assim, observar traços estruturais das línguas crioulas que possam interferir no processo de nasalidade e, em trabalhos futuros, testar o domínio das demais línguas locais como possível variável relevante para o fenômeno.
} 


\begin{tabular}{|c|c|}
\hline Tônica & Pretônica \\
\hline banana $\mathrm{x}$ nando $\mathrm{x}$ nado & banana $\mathrm{x}$ bambu $\mathrm{x}$ babu \\
\hline cama $\mathrm{x}$ canto $\mathrm{x}$ cato & camada $\mathrm{x}$ cancan $\mathrm{x}$ kaká \\
\hline cano $\mathrm{x}$ canto $\mathrm{x}$ cato & caneta $\mathrm{x}$ cancan $\mathrm{x}$ kaká \\
\hline mana $\mathrm{x}$ manta $\mathrm{x}$ mata & \\
\hline
\end{tabular}

Quadro 2: Contraposição de dados analisados.

Por fim, elaboradas as análises acústicas, foi atribuída uma interpretação fonológica aos dados de nasalização heterossilábica e, posteriormente, os resultados foram comparados à literatura do mesmo fenômeno no santome (Bandeira 2017) e no lung'le (Agostinho 2015; Bandeira 2017), bem como no PB e no PE (Miguel 2006; Moraes e Wetzels 1992; Souza e Pacheco 2012, entre outros).

\section{Nasalização heterossilábica no PST e no PP}

Esta seção é destinada à descrição e análise da nasalização vocálica heterossilábica no PST e no PP. Para tanto, inicialmente, realizamos uma descrição acústica do processo e, em seguida, sugerimos uma interpretação fonológica para o fenômeno.

\section{Descrição acústica}

A nasalidade heterossilábica, no PST e no PP, foi analisada de acordo com as seguintes etapas: (i) análise perceptual da produção da nasalidade; (ii) análise espectral, na qual os dados com nasalização heterossilábica foram contrapostos aqueles com nasalização tautossilábica; (iii) mensuração dos segmentos vocálicos nasais $\tilde{V}$.N comparados à duração de $\tilde{V} \mathrm{~N}$ e (iv) análise formântica da vogal em construções V.N.N.

$\mathrm{Na}$ etapa preliminar de exame dos dados, as vogais que perceptivelmente exibiam nasalidade foram discriminadas daquelas que não indicavam qualquer processo de nasalização. $O$ resultado pode ser auferido no quadro 3 para o PST e no quadro 4 para o PP. 


\begin{tabular}{|c|l|c|c|c|c|c|}
\hline $\begin{array}{c}\text { Posição na } \\
\text { Sílaba }\end{array}$ & \multicolumn{1}{|c|}{ Item Lexical } & I & II & III & IV & V \\
\hline \multirow{4}{*}{ Tônica } & banana & $\checkmark$ & $\checkmark$ & $\checkmark$ & $\checkmark$ & $\checkmark$ \\
\cline { 2 - 7 } & cama & $\mathrm{X}$ & $\checkmark$ & $\checkmark$ & $\mathrm{X}$ & $\checkmark$ \\
\cline { 2 - 7 } & cano & $\checkmark \sim \mathrm{X}$ & $\checkmark$ & $\checkmark$ & $\checkmark$ & $\checkmark$ \\
\cline { 2 - 7 } & mana & $\checkmark$ & $\checkmark$ & $\checkmark$ & $\checkmark \sim \mathrm{X}$ & $\checkmark$ \\
\hline \multirow{3}{*}{ Pretônica } & banana & $\mathrm{X}$ & $\mathrm{X}$ & $\mathrm{X}$ & $\mathrm{X}$ & $\mathrm{X}$ \\
\cline { 2 - 7 } & camada & $\mathrm{X}$ & $\mathrm{X}$ & $\mathrm{X}$ & $\mathrm{X}$ & $\mathrm{X}$ \\
\cline { 2 - 7 } & caneta & & $\mathrm{X}$ & $\mathrm{X}$ & $\mathrm{X}$ & $\mathrm{X}$ \\
\hline
\end{tabular}

Quadro 3: Itens lexicais nasalizados a partir de nasalização heterossilábica no PST.

A numeração I, II, III, IV e V equivale aos diferentes informantes.

\begin{tabular}{|c|l|c|c|c|c|c|}
\hline $\begin{array}{c}\text { Posição na } \\
\text { Sílaba }\end{array}$ & \multicolumn{1}{|c|}{ Item Lexical } & I & II & III & IV & V \\
\hline \multirow{4}{*}{ Tônica } & banana & $\checkmark$ & $\checkmark$ & $\checkmark$ & $\checkmark$ & $\checkmark \sim \mathrm{X}$ \\
\cline { 2 - 7 } & cama & $\checkmark \sim \mathrm{X}$ & $\checkmark$ & $\checkmark$ & $\checkmark$ & $\checkmark$ \\
\cline { 2 - 7 } & cano & $\checkmark \sim \mathrm{X}$ & $\checkmark$ & $\checkmark$ & $\checkmark \sim \mathrm{X}$ & $\checkmark$ \\
\cline { 2 - 7 } & mana & $\checkmark$ & $\checkmark$ & $\checkmark$ & $\checkmark$ & $\checkmark$ \\
\hline \multirow{3}{*}{ Pretônica } & banana & $\mathrm{X}$ & $\mathrm{X}$ & $\mathrm{X}$ & $\mathrm{X}$ & $\mathrm{X}$ \\
\cline { 2 - 7 } & camada & $\mathrm{X}$ & $\mathrm{X}$ & $\mathrm{X}$ & $\mathrm{X}$ & $\mathrm{X}$ \\
\cline { 2 - 7 } & caneta & $\mathrm{X}$ & $\mathrm{X}$ & $\mathrm{X}$ & $\mathrm{X}$ & $\mathrm{X}$ \\
\hline
\end{tabular}

Quadro 4: Itens lexicais nasalizados a partir de nasalização heterossilábica no PP.

A numeração I, II, III, IV e V equivale aos diferentes informantes.

Ao considerar $(\checkmark)$ como o indicador dos casos de nasalização, $(\mathrm{X})$ como a não realização do processo e $(\checkmark \sim X)$, como a realização opcional do processo (variação encontrada no mesmo informante), dois fatos, indicados nos quadros 1 e 2, se destacam: (i) não foi constatada nasalização heterossilábica em sílabas pretônicas e PP. Portanto, em todos os casos e para ambas as variedades, a sílaba tônica é o alvo do espalhamento, se seguida por uma consoante nasal na sílaba seguinte; e (ii) em uma sílaba pretônica, a nasalização de [a] não corre, mesmo se seguida por uma consoante nasal na sílaba tônica seguinte.

Os dados do PST (quadro 3) revelam que a vogal [a] na posição tônica, seguida por uma consoante nasal no onset da sílaba seguinte, é realizada nasalizada, com exceção dos informantes I e IV, que realizaram cama como ['ka.me] e cano e mana ora como ['ka.nu] e ['ma.ne], ora como

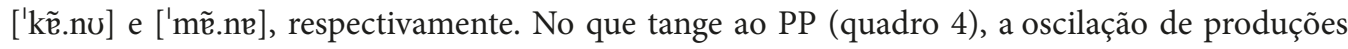
nasais e orais foi observada nos dados do informante II, para o qual cama foi produzido ora como ['ka.me], ora como ['kẽe.me]. O mesmo ocorreu com cano ['kẽe.nu] ['ka.nu] e, também, nos da- 


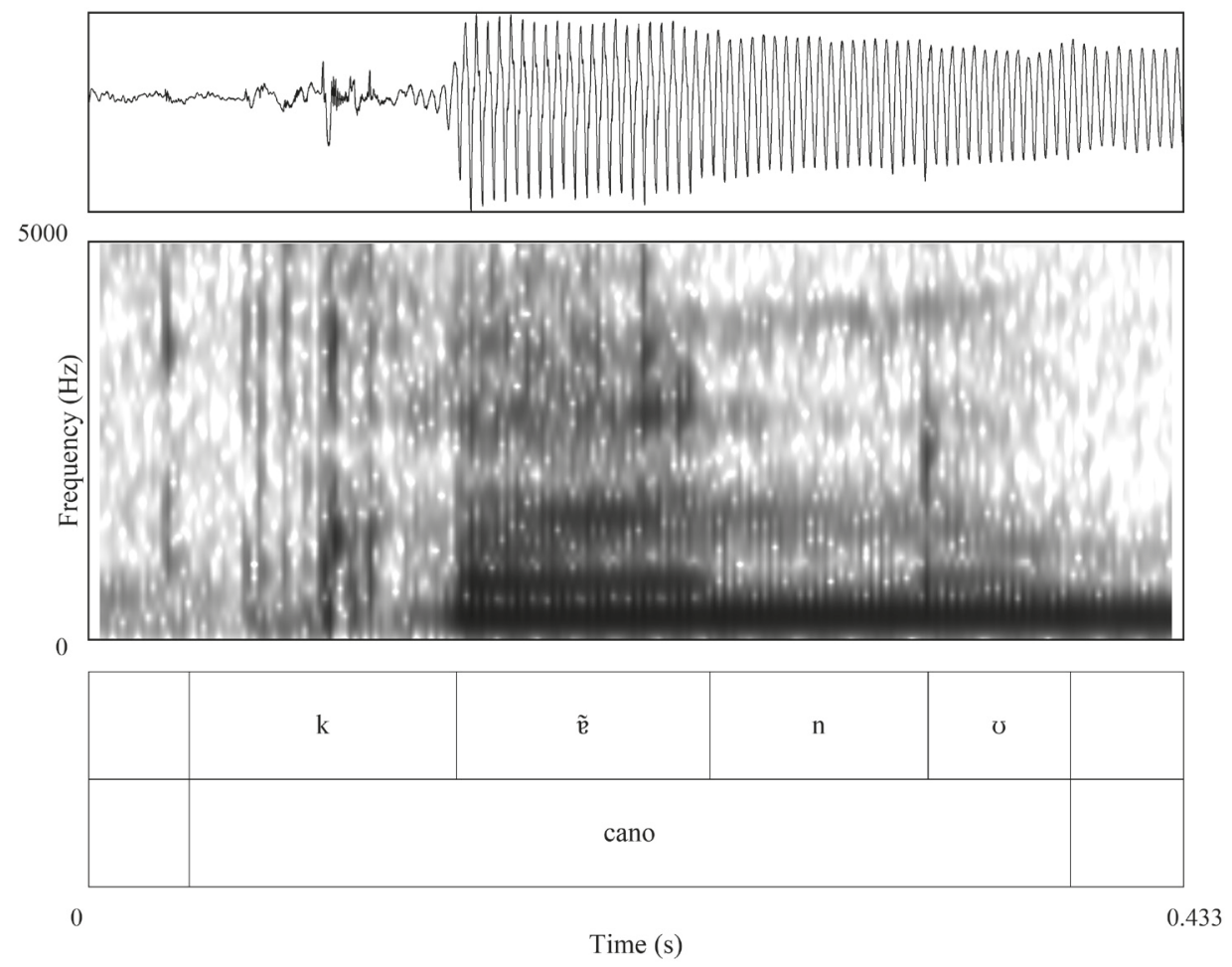

Figura 1: Palavra cano ['kẽ.nu] no PP, sem murmúrio nasal.

dos do informante $\mathrm{V}$, nos quais vemos duas possibilidades para banana [ba.'na.ne] [ba.'ñ̃.ne]. Ademais, o [a] do item lexical cano foi oralizado pelo informante IV, realizando-se como ['ka.nu].

As produções com vogais orais de cama, mana, cano e banana revelam um comportamento distinto da nasalidade heterossilábica do PST e do PP em relação ao PB e ao PE. De fato, realizações sem nasalidade vocálica, em sílabas tônicas, comumente não são encontradas no PB e no PE. Dessa forma, essa poderia ser uma característica inerente ao PST e ao PP. Contudo, para testarmos essa hipótese, e comprovarmos a natureza distinta entre as vogais nasais tautossilábicas e as vogais nasalizadas no PST e no PP, seria necessário analisar a presença do murmúrio nasal, uma das características da nasalidade produzida por coda nasal, bem como a duração do segmento e dos formantes que compõem as estruturas-alvo. Assim, o espectrograma das vogais nasalizadas revela a ausência do apêndice nasal (figura 1), enquanto este murmúrio foi detectado em todos os casos (figura 2) para a vogal nasal, como exemplificado.

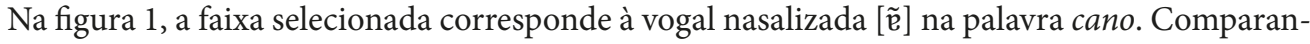
do esta produção, com a produção de canto (figura 2), é possível observar a ausência do murmúrio nasal. Logo após a produção da vogal, no espectograma, é a forma de onda da consoante [n] que está presente no onset da sílaba seguinte, embora aproxime-se da forma identificada para o murmúrio nasal da coda da sílaba. Na figura 2, por sua vez, notamos pela faixa selecionada, a presença da vogal [ $\tilde{\mathfrak{e}}]$ seguida do murmúrio nasal. Este, no que tange à forma de onda, exibe menos picos 

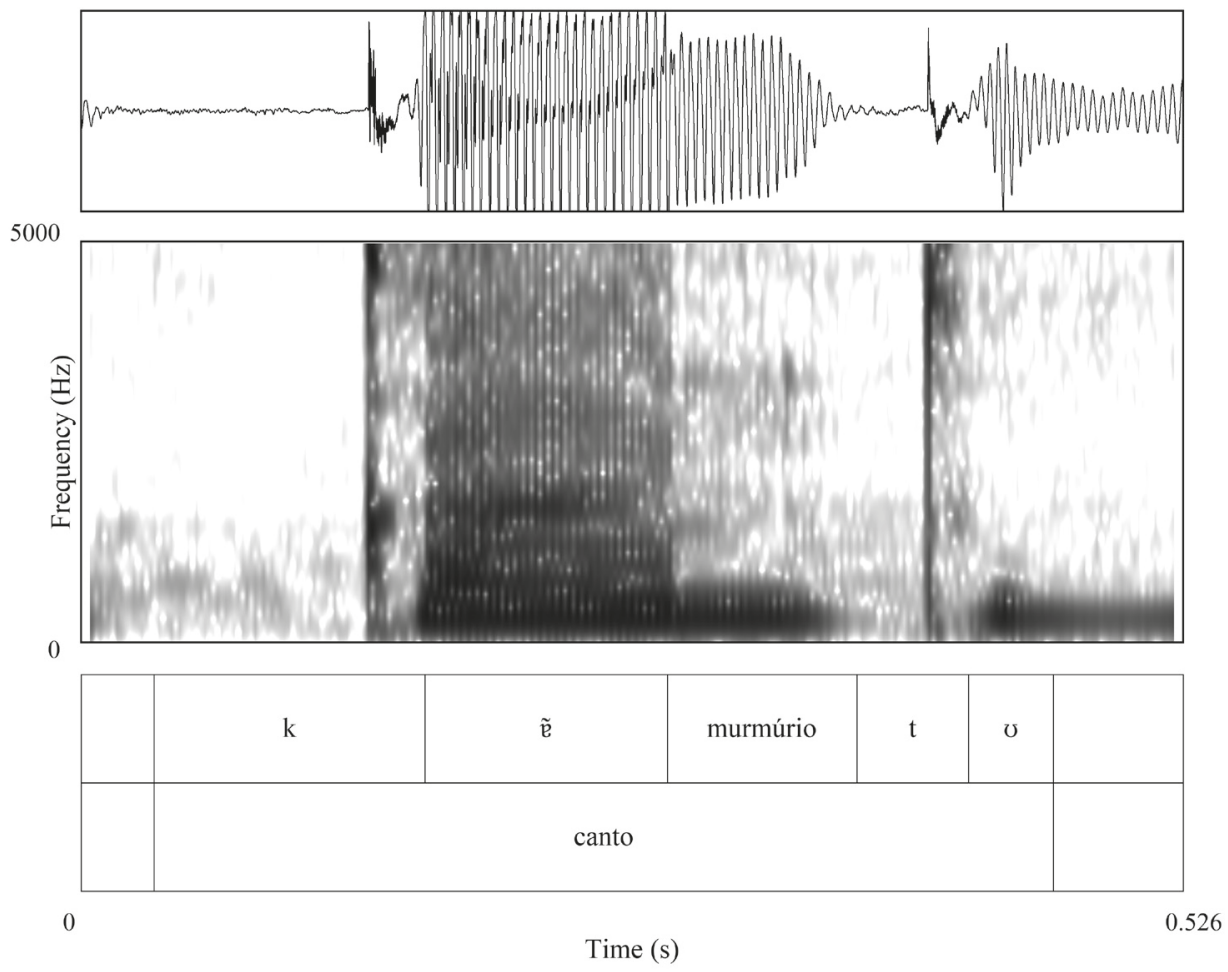

Figura 2: Palavra canto ['kẽ.tu] no PP, com murmúrio nasal.

em relação às vogais, e, como consequência, sua periodicidade é distinta. No espectro, seu início é assinalado pelo fim de F2 da vogal e pela perda de intensidade, caracterizando-se por ser uma faixa espectral mais clara em relação à faixa da vogal. Portanto, nos casos de nasalização heterossilábica, o apêndice nasal não é observável (figura 2), ao passo que o é nos casos de nasalidade tautossilábica (figura 1). Essa diferença de processos é ainda mais acentuada ao analisarmos as durações vocálicas orais, nasais e nasalizadas, as quais reforçam a diferença entre os processos.

O espalhamento de nasalidade vocálica tautossilábica distingue-se do processo de nasalização engatilhado por onset nasal..$^{8}$ Como são frequentemente interpretadas como tendo uma estrutura bifonêmica, as vogais nasalizadas em coda apresentam uma duração mais longa quando comparadas às suas contrapartes orais, pois sua duração corresponde a uma dupla associação do segmento vocálico na camada silábica, decorrente do processo de espalhamento da nasalização e, posterior apagamento da consoante nasal na coda (Moraes e Wetzels 1992). Essa estrutura bifonêmica, poderia ser demonstrada, em grande parte das vezes, por meio de um apêndice nasal, isto é, um segmento acústico associado a uma radiação exclusivamente nasal da energia sonora (Kent e Read 2015), que indicaria um correlato acústico da consoante nasal em coda elidida da camada segmental. $\mathrm{O}$ alongamento vocálico característico às vogais nasais é confirmado em estudos dedi-

8 Uma das diferenças se deve ao fato de a nasalidade vocálica tautossilábica não ser sensível ao acento lexical e poder gerar oposição significativa (Balduino 2018; Câmara Jr. 1970; Moraes e Wetzels 1992). 
cados às diferentes variedades do português, os quais apontam ser a vogal nasal consistentemente mais longa em relação à sua contraparte oral (Araujo e Balduino 2019; Balduino 2018; Barbosa e Madureira 2015; Moraes e Wetzels 1992). Em relação ao PST e ao PP, notamos que o alongamento das vogais nasais também é atestado e, por meio da contraposição de pares mínimos cuja distinção de significado dos itens lexicais era produzida apenas pela ausência ou presença de uma vogal [+nasal]. Balduino (2018), por exemplo, constata que a sequência ṼN é mais longa em relação a uma vogal oral similar (sem coda nasal), sendo esse alongamento, de $48 \%$ no PST e de $60 \%$ no PP, em média, considerando-se sílabas tônicas e pretônicas.

Na tabela 1, ao contrapormos os valores médios dos cinco informantes do PST e do PP para os dados que apresentaram nasalidade heterossilábica ( $\tilde{V} . \mathrm{N})$, com os valores, desses mesmos informantes, para a nasalidade tautossilábica $(\tilde{\mathrm{V} N})$ e para as vogais orais $(\mathrm{V})$ em posição tônica, constatamos que a vogal nasal é, em média, 40\% mais longa em relação à vogal oral, em ambas as variedades, ao passo que a vogal oral é, em média, 12\% alongada em relação à vogal nasalizada, no PST, e $38 \%$ no PP.

\begin{tabular}{|c|c|c|c|c|c|c|}
\hline \multirow{3}{*}{$\boldsymbol{P S T}$} & Vogal & $\tilde{\mathrm{V}} . \mathrm{N}$ & $\tilde{\mathrm{V}} \mathrm{N}$ & $\mathrm{V}$ & D1 \% & D2 \% \\
\cline { 2 - 7 } & {$[\mathrm{a}]$} & 130.2 & 203.8 & 146.4 & 39.7 & 12.4 \\
& 130 & 204 & 146 & 40 & 12 \\
\hline \multirow{3}{*}{$\boldsymbol{P P}$} & Vogal & $\tilde{\mathrm{V}} . \mathrm{N}$ & $\tilde{\mathrm{V} N}$ & $\mathrm{~V}$ & D1 \% & D2 \% \\
\cline { 2 - 7 } & {$[\mathrm{a}]$} & 89.9 & 173.1 & 124.1 & 39.5 & 38 \\
& 90 & 174 & 124 & 40 & 38 \\
\hline
\end{tabular}

Tabela 1: Duração média da vogal oral em oposição às formas nasalizadas em posição tônica no PST e no PP. D1 equivale à diferença percentual entre $\tilde{\mathrm{V}} \mathrm{N}$ e V e D2 equivale à diferença percentual entre $\tilde{\mathrm{V}}$. $\mathrm{N}$ e $\mathbf{V}$.

O fato de a vogal nasalizada ser mais curta em relação à vogal oral, enquanto a vogal nasal é mais longa quando comparada a esta, é capaz de descartar explicações puramente articulatórias para ambos os processos de nasalização no PST e no PP. De acordo com esta perspectiva, tanto a nasalidade tautossilábica, produzida por coda nasal, quanto a nasalidade heterossilábica, produzida a partir do onset nasal contíguo, sugeririam uma maior duração das vogais nasais e nasalizadas por conta do gesto articulatório complementar exigido na produção desses sons (ver Moraes e Wetzels 1992 para o PB). Como pode ser constatado na tabela 1 , as vogais nasalizadas, distintamente das vogais nasais, apresentam duração média inferior, inclusive, ao serem contrapostas às vogais orais, mesmo apresentando nasalidade em decorrência do acoplamento das cavidades orais e nasais no momento de sua produção, visto que na produção dos sons [+nasais] o ar escapa por ambas as cavidades. Essa diferença duracional, atestada entre as vogais nasalizadas e as vogais orais enfatiza a existência de dois processos de nasalização com consequências fonéticas distintas no PST e no PP: (i) o espalhamento da nasalidade tautossilábica, caracterizada pela presença do murmúrio nasal e pelo alongamento da vogal na sequência $\tilde{V} N$ em relação à $V$, onde $\tilde{V} N$ equivale à sequência bifonêmica /VN/ na forma subjacente (Balduino 2018) e (ii) o espalhamento da nasalidade heterossilábica, caracterizada pela menor duração da vogal em sequências V.N em tônicas, 
mesmo em relação à vogal oral, e pela exigência de uma consoante nasal no onset nasal subsequente para o espraiamento do traço de nasalidade.

Assim, para a nasalidade heterossilábica no PST e no PP, podemos apontar, como característica acústica, a menor duração de seus segmentos em relação às vogais nasais e às vogais orais, bem como a ausência do murmúrio nasal, um dos elementos que caracterizam o espalhamento da nasalidade tautossilábica via coda nasal. Todavia, embora a menor duração possa diferenciar a vogal nasalizada da vogal nasal e oral, este não é um fator suficientemente forte para apontar a nasalização destes segmentos e indicar a ausência da nasalização em palavras como cama, cano e mana. Dessa forma, tendo em vista os quadros 1 e 2, e visando investigar outros parâmetros acústicos que possam determinar o estatuto das vogais nasalizadas, examinemos os formantes que compõem as vogais nasalizadas. Para tanto, extraímos os valores dos formantes F1, F2 e F3, a partir da porção medial do segmento e contrapomos os resultados obtidos para as vogais nasalizadas, com os valores médios das vogais nasais e orais, calculados a partir de duas repetições dos itens lexicais para cada informante. Na tabela 2, estão arrolados os dados para o PST e, na tabela 3, para o PP.

\begin{tabular}{|cccc|}
\hline Formantes & {$[\tilde{\mathrm{e}} . \mathrm{N}]$ nasalizada } & {$[\tilde{\mathrm{eN}}]$ nasal } & {$[\mathrm{a}]$ oral } \\
\hline $\mathrm{F} 1 \mathrm{~Hz}$ & 637,2 & 635,8 & 721,2 \\
\hline $\mathrm{F} 2 \mathrm{~Hz}$ & 1394,6 & 1407,1 & 1420,8 \\
\hline $\mathrm{F} 3 \mathrm{~Hz}$ & 2478,6 & 2274 & 1911,9 \\
\hline
\end{tabular}

Tabela 2: Média dos formantes da vogal nasalizada, nasal e oral no PST. Os valores estão em Hertz (Hz).

\begin{tabular}{|cccc|}
\hline Formantes & {$[\tilde{\text { e.N }}]$ nasalizada } & {$[\tilde{\mathrm{eN}}]$ nasal } & {$[\mathrm{a}]$ oral } \\
\hline $\mathrm{F} 1 \mathrm{~Hz}$ & 434,5 & 479,9 & 716,4 \\
\hline $\mathrm{F} 2 \mathrm{~Hz}$ & 1489,2 & 1554,6 & 1636,5 \\
\hline $\mathrm{F} 3 \mathrm{~Hz}$ & 2717,7 & 2772,7 & 2975,5 \\
\hline
\end{tabular}

Tabela 3: Média dos formantes da vogal nasalizada, nasal e oral no PP. Os valores estão em Hertz (Hz).

A partir dos resultados indicados nas tabelas 2 e 3, notamos que o F1 das vogais [ $\tilde{\mathrm{e} N}$ ] nasal

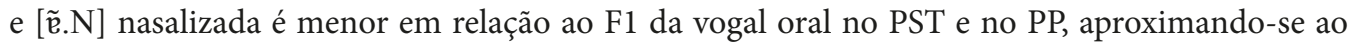

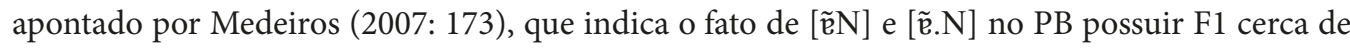
100-200 Hz menor quando contraposta ao F1 de [a]. ${ }^{9}$

No caso dos dados apresentados para o PST, o F1 de [ $\tilde{\mathrm{e} N}]$, das palavras que apresentam a vogal nasal, é cerca de 95,4 Hz menor, em média, do que o F1 de [a] dos itens com vogais orais.

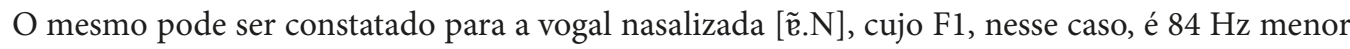
em relação ao F1 de [a]. Para o PP, por seu turno, a diferença entre o F1 das vogais com traço de

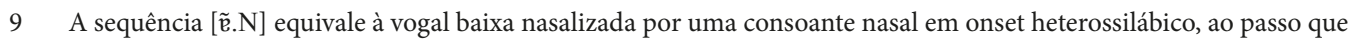
$[\tilde{\mathfrak{v}} \mathrm{N}]$ corresponde à vogal baixa nasalizada por uma consoante nasal tautossilábica em coda. 
nasalidade é ainda ampliada quando contraposta ao F1 da vogal oral. Assim, tanto a vogal nasa-

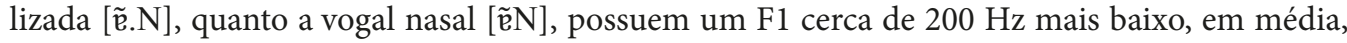
do que o F1 da vogal oral. A queda do valor em $\mathrm{Hz}$ de F1 tanto no PST, quanto no PP, indica que a vogal [a], quando nasalizada é produzida com a elevação da mandíbula e, independentemente da natureza do processo de espraiamento, seja a partir da coda, seja do onset nasal.

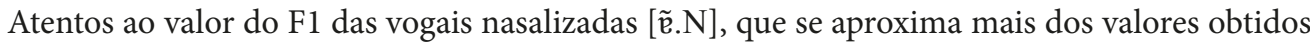
para a vogal nasal [ $\tilde{\mathfrak{e}} \mathrm{N}]$, sendo ambos mais baixos do que o F1 de [a], podemos voltar aos itens com uma vogal [a] oral, mesmo em contexto propício para a nasalização heterossilábica obrigatória no $\mathrm{PB}$ e no PE. Desse modo, para comprovar a oralidade dos segmentos nesse contexto, comparamos o F1 dos segmentos orais de cada informante, com os valores médios de F1 nasalizada, de F1 nasal e de F1 oral. Nossa hipótese era de que, caso o segmento tenha sido oralizado de fato, ele poderia conter um F1 mais elevado e próximo ao primeiro formante da vogal oral, pois haveria a possibilidade de a mandíbula estar baixa na produção de [a]. Logo, o segmento [a], sem a nasalidade para alimentar a regra de alçamento, permaneceria baixo. Se isso ocorresse, nossa análise perceptiva seria confirmada, bem como a não obrigatoriedade da aplicação da nasalidade heterossilábica no PST e no PP. A análise é exposta, na tabela 4, para o PST e, na tabela 5, para o PP.

\begin{tabular}{|c|c|c|c|c|}
\hline \multicolumn{5}{|c|}{ Informante I } \\
\hline Item & $\begin{array}{c}\text { F1 de [a] não } \\
\text { nasalizada }\end{array}$ & 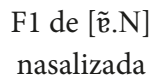 & $\begin{array}{c}\text { F1 de }[\widetilde{e} N] \\
\text { nasal }\end{array}$ & $\begin{array}{c}\text { F1 de }[\mathrm{a}] \\
\text { oral }\end{array}$ \\
\hline cano & 941,3 & 764,9 & 705,9 & 941,5 \\
\hline cama & 958,9 & 694,4 & 709,7 & 941,5 \\
\hline \multicolumn{5}{|c|}{ Informante IV } \\
\hline Item & $\begin{array}{c}\text { F1 de [a] não } \\
\text { nasalizada }\end{array}$ & 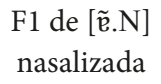 & $\begin{array}{c}\text { F1 de }[\widetilde{\mathrm{eN}}] \\
\text { nasal }\end{array}$ & $\begin{array}{c}\text { F1 de }[\mathrm{a}] \\
\text { oral }\end{array}$ \\
\hline cano & 900 & 637,2 & 610,8 & 799,2 \\
\hline cama & 912 & 637,2 & 610,8 & 799,2 \\
\hline
\end{tabular}

Tabela 4: Valores de F1 para as realizações orais em contexto de nasalização heterossilábica contraposto às médias gerais dos formantes identificados para a vogal nasal e oral no PST. Os valores estão em Hertz (Hz).

No que diz respeito aos informantes I e IV, pela mensuração dos formantes, confirmamos como oral a produção de [a] em cama, cano e mana, posto que, como é apontado na tabela 4, o F1 de tais itens se mantém elevado e se aproxima mais da média oral, podendo, inclusive, ser maior em relação a esta. Ao contrapormos o F1 de [a] na sílaba inicial mana e mata, por exemplo, a qualidade oral da vogal é reforçada, pois obtivemos o mesmo valor de $912 \mathrm{~Hz}$. Comparando o F1 de cama e cato, constatamos que aquele possui $900 \mathrm{~Hz}$, ao passo que, para o informante IV, este exibe a frequência de $706 \mathrm{~Hz}$. Essa diferença entre os valores do primeiro formante é também constatada nas produções do informante I, nas quais notamos que o valor médio de F1 de [a] em cama é de 958,9 $\mathrm{Hz}$, ao passo que cato possui F1 em torno de $941,5 \mathrm{~Hz}$. 


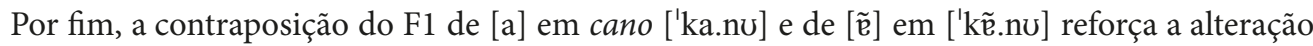
de F1 em decorrência da nasalização da vogal baixa, uma vez que quando produzido de forma oral pelo informante I, cano apresenta o F1 de $941,5 \mathrm{~Hz}$ e, ao ser realizado de modo nasalizado, o F1

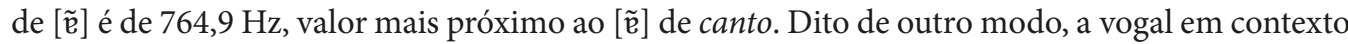
de nasalização, porém não nasalizada, tem F1 igual ou maior quando contraposta ao F1 da vogal oral, indicando que, no momento de sua produção, a mandíbula estava baixa, mesmo que a vogal não tenha sido efetivamente nasalizada. Consequentemente, para o PST, a natureza oral dos dados cano, cama e mana produzidos pelos informantes I e IV foi confirmada.

Para o PP, os dados não nasalizados foram mais numerosos e recorrentes entre os informantes, mesmo estando em contexto de espalhamento de nasalidade heterossilábica, obrigatório para o PE e para o PB. Assim, na tabela 5, podemos notar o valor de F1 de [a] da sílaba tônica dos itens banana, cama e cano, contraposto ao valor médio de F1 de itens nasais e orais para os informantes I, IV e V.

\begin{tabular}{|c|c|c|c|c|}
\hline \multicolumn{5}{|c|}{ Informante I } \\
\hline Item & $\begin{array}{c}\text { F1 de [a] não } \\
\text { nasalizada }\end{array}$ & 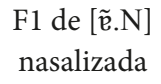 & $\begin{array}{c}\text { F1 de }[\tilde{e} \mathrm{~N}] \\
\text { nasal }\end{array}$ & $\begin{array}{c}\text { F1 de [a] } \\
\text { oral }\end{array}$ \\
\hline cano & 728,6 & 577,6 & 632,1 & 797,2 \\
\hline cama & 811,2 & 577,6 & 632,1 & 797,2 \\
\hline \multicolumn{5}{|c|}{ Informante IV } \\
\hline Item & $\begin{array}{c}\text { F1 de [a] não } \\
\text { nasalizada }\end{array}$ & $\begin{array}{c}\text { F1 de }[\tilde{\mathrm{e}} . \mathrm{N}] \\
\text { nasalizada }\end{array}$ & $\begin{array}{c}\text { F1 de }[\tilde{\mathrm{e} N}] \\
\text { nasal }\end{array}$ & $\begin{array}{c}\text { F1 de }[\mathrm{a}] \\
\text { oral }\end{array}$ \\
\hline cano & 618,6 & 312,6 & 481,5 & 714,3 \\
\hline \multicolumn{5}{|c|}{ Informante IV } \\
\hline Item & $\begin{array}{c}\text { F1 de [a] não } \\
\text { nasalizada }\end{array}$ & 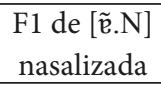 & $\begin{array}{c}\text { F1 de }[\tilde{\mathrm{e} N}] \\
\text { nasal }\end{array}$ & $\begin{array}{c}\text { F1 de [a] } \\
\text { oral }\end{array}$ \\
\hline banana & 591,4 & 347,7 & 353,5 & 590,8 \\
\hline
\end{tabular}

Tabela 5: Valor de F1 para as realizações orais em contexto de nasalização heterossilábica contraposto às médias gerais dos formantes identificados para a vogal nasal e oral no PP. Os valores estão em Hertz (Hz).

No PP, a natureza oral da vogal em contexto de nasalização heterossilábica é confirmada, corroborando, assim, a não obrigatoriedade do processo de nasalização para a vogal aberta [a] em sílabas tônicas sucedidas por um onset nasal, de forma semelhante ao PST. No gráfico 1, observamos, em suma, que a despeito da diferença dos valores de F1 entre as variedades, os quais foram consistentemente mais altos para o PST, o F1 do PST e do PP apresentam a mesma tendência: o F1 de $[$ a.N] é maior, ao passo que o $\mathrm{F} 1$ de $[\tilde{\mathrm{e} N}]$ e $[\tilde{\mathrm{e}} . \mathrm{N}]$ são equivalentes. 


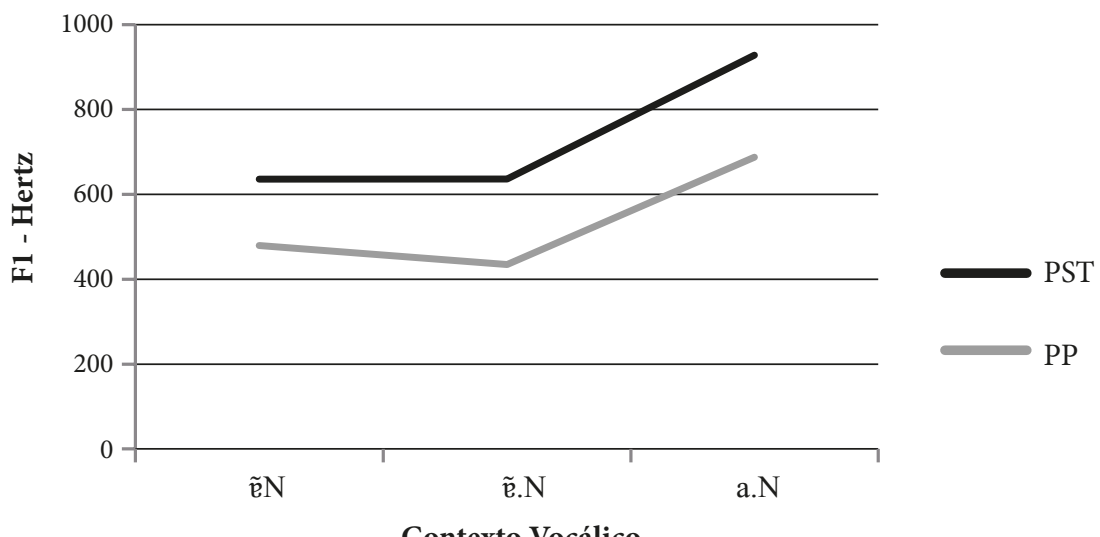

Contexto Vocálico

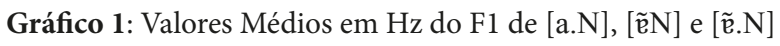

A nasalização heterossilábica da vogal baixa [a], nas variedades estudadas, é, acusticamente, caracterizada pela: (i) elevação da mandíbula e consequente queda em Hertz no valor de F1; (ii) ausência do apêndice nasal e (iii) ausência de alongamento vocálico. Contrapondo esses reflexos fonéticos com os reflexos encontrados para o processo de nasalização tautossilábica (Balduino 2018), notamos que, com exceção da elevação da mandíbula e a queda do primeiro formante, a nasalização heterossilábica comporta-se de maneira distinta em relação à nasalização produzida por uma coda nasal, mesmo que ambas sejam engatilhadas por uma consoante nasal.

\begin{tabular}{ll}
\hline Nasalidade Heterossilábica & Nasalidade Tautossilábica \\
\hline Elevação da mandíbula & Elevação da mandíbula \\
\hline Queda de F1 & Queda de F1 \\
\hline Ausência do apêndice nasal & Apêndice nasal \\
\hline Ausência do alongamento vocálico & Alongamento vocálico \\
\hline
\end{tabular}

Quadro 5: Descrição acústica dos processos de nasalização no PST e no PP.

As divergências da caracterização acústica dos processos de nasalização vocálica podem estar relacionadas à queda da consoante nasal em coda nos casos de nasalização tautossilábica, pois, na nasalização heterossilábica, a consoante nasal não está sujeita a apagamentos e, por isso, não sofre alongamento vocálico ou indica qualquer resquício fonético de uma consoante nasal elidida, como no caso do apêndice. Neste artigo, nos detemos à caracterização duracional, espectral e formântica do fenômeno, já que, como discutido ao longo da seção, esses são fatores acústicos relevantes para a distinção entre os processos de nasalização, bem como entre as vogais nasalizadas e orais no PST e no PP. Porém, esses não são os únicos elementos acústicos possíveis de descrição e, 
em trabalho futuros, uma investigação dos formantes nasais para a caracterização mais detalhada do fenômeno seria positiva.

\section{Caracterização fonológica}

Diante dos resultados, concluímos que, no PST e no PP, há um processo de espalhamento de nasalização heterossilábica. A consoante nasal no onset espraia o traço [+nasal] para a vogal adjacente na sílaba anterior, a qual passa a ser nasalizada, como representado em (6). Aproximando essas variedades do $\mathrm{PB}$ e do $\mathrm{PE}$, nas quais o processo é engatilhado a partir da consoante nasal em onset adjacente à vogal-alvo.

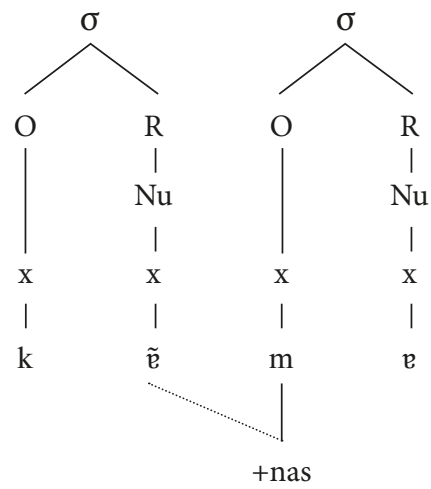

A assimilação da nasalidade ocorre regressivamente ${ }^{10}$, isto é, a consoante nasal no onset nasaliza

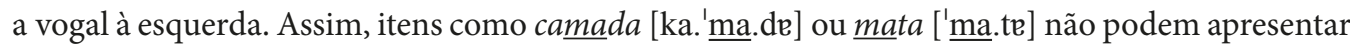
nasalidade regressiva e nem a consoante nasal espraia o seu traço [+nasal] para a vogal na mesma sílaba. Ademais, o espraiamento da nasalidade é bloqueado quando há uma consoante na coda na sílaba em que a vogal-alvo está inserida. Logo, itens como carne e alma, por exemplo, não podem ter o [a], na sílaba inicial, nasalizado, posto que a consoante em coda bloqueia o espraiamento, indicando que a assimilação de traços não promove o cruzamento de linhas de associação e, portanto, não ultrapassa seu nó de raiz.

O processo de nasalização heterossilábica não envolve ressilabificação e, embora a consoante nasal compartilhe um de seus traços com a vogal adjacente à esquerda, ela não é elidida da camada segmental ou realocada na posição de coda. Em decorrência disso, ambos os fonemas envolvidos nesse processo, isto é, /a/ e / $/ \mathrm{m} / \mathrm{ou} / \mathrm{n} /$, são associados individualmente a uma uni-

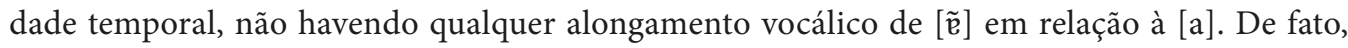
por ser [a] uma vogal baixa e aberta, sua duração vocálica é maior em relação à [ể], produzida com a elevação da mandíbula. Concluímos, desse modo, que mesmo que a nasalização vocálica heterossilábica seja engatilhada por uma consoante nasal, como no caso da nasalização vocá-

10 Moraes (2003) sugere que, no PB, a nasalização heterossilábica, denominada pelo autor como alofônica, também pode ocorrer progressivamente como em muito m[u]ito. Porém, esse argumento será descartado por se tratar de um hápax. 
lica tautossilábica, o acento lexical é um dos fatores que devem ser considerados. A princípio, o acento pode delimitar a possibilidade de aplicação do processo promovido por um onset nasal, porém é indiferente à nasalização promovida pelo espraiamento do traço nasal a partir da coda. Ademais, os processos também apresentam reflexos fonéticos particulares, como o alongamento da duração vocálica e a presença de murmúrio nasal identificados apenas paras as vogais nasais $(\tilde{\mathrm{V} N})$, em contraste com a menor duração e ausência do apêndice nasal nas vogais nasalizadas ( $\mathrm{V} . \mathrm{N})$.

Adicionalmente, nos dados analisados, não houve nasalização heterossilábica em pretônicas. Assim, a vogal baixa átona da sequência [CV.'NV] foi realizada de forma plenamente oral. Ao mesmo tempo, a nasalidade heterossilábica em itens lexicais tônicos não se mostrou obrigatória, distintamente do PB e do PE, sendo a vogal tônica de ['CV.NV], ora nasalizada, ora produzida como oral. A opcionalidade na aplicação da nasalização heterossilábica em tônicas aproxima o PST ao santome e o PP ao lung'Ie (Agostinho 2015; Bandeira 2017), na medida em que nessas línguas o fenômeno é também facultativo no contexto abordado, como demonstrado no santome mana ['ma.na] ['mẽ.na] 'irmã', no qual a primeira sílaba, mesmo portanto o acento lexical da palavra e estando contígua a uma sílaba iniciada por consoante nasal, não é necessariamente nasalizada.

A delimitação das ocorrências com espraiamento da nasalização heterossilábica apenas em sílabas tônicas pode ser relacionada, ainda, ao domínio do pé métrico. Hayes (1995) define o pé métrico como uma unidade composta por duas ou mais sílabas na qual podemos identificar uma relação de dominância, sendo uma sílaba a cabeça $\left(^{*}\right)$ e as demais recessivas $(\cdot)$ (Ewen e Hulst 2001). Para a atribuição do acento lexical, assume-se que os pés podem ser organizados da esquerda para a direita ou da direita para esquerda. Bisol $(1992,1994)$ postula que o pé métrico deve ser construído a partir da borda direita da palavra, com proeminência à esquerda, constituindo, assim, pés do tipo troqueu ${ }^{*} \cdot$ ), para explicar a atribuição do acento primário no PB. Com base nessa generalização, atribuímos uma organização métrica para os dados que compõem nosso corpus de análise como indicado em (7).

a. $<$ ba $>$ nana

$(* \cdot)$ b. $<$ ca $>$ mada

$(* \cdot)$ c. cama

$(* \cdot)$ d. mana

$(* \cdot)$

Nos exemplos em (7), a cabeça $\left(^{*}\right)$ do pé coincide com a sílaba mais proeminente da palavra e, por isso, podemos identificar que o espraiamento do traço [+nasal] para a vogal-alvo só é possível, dentro do domínio do pé, caso a vogal-alvo esteja na sílaba tônica que coincida com a cabeça do pé. Assim, em banana (7.a), observamos que o [n] da última sílaba pode espraiar a nasalidade para [a] da cabeça do pé, pois ambas as sílabas são agrupadas dentro de um único pé, porém, não identificamos o espraiamento de [n], da segunda sílaba, para o [a] da primeira sílaba nos dados. O mesmo ocorre em camada (7.b), item no qual não foi observada a nasalização da primeira sílaba por nenhum dos informantes, sugerindo que estar fora do domínio do pé binário pode ser um fator relevante para aplicação ou não do fenômeno no PST e no PP, além de se tratar de uma sílaba átona. Em mana (7.c) e em cama (7.d), por seu turno, as sílabas estão no mesmo domínio, $<$ ma $>$ e $<$ ca $>$ correspondem à cabeça do pé, constituindo, também, a sílaba tônica da palavra, e, portanto, admitem a nasalização de [a]. 
Assumir que o processo de nasalização heterossilábica tem como domínio de aplicação o pé implica reconhecer que o processo pode ser concretizado dentro deste domínio, desde que a vogal-alvo esteja na sílaba proeminente do pé. Portanto, o que delimitaria o espraiamento do traço [+nasal] seria a cabeça do pé, a qual nem sempre coincide com a sílaba tônica, como é o caso das palavras formadas por quatro sílabas ou mais. Sendo assim, para verificarmos as condições que permitem o espraiamento da nasalidade, ampliamos o corpus, analisando a aplicação do fenômeno em itens lexicais formados por, pelo menos, dois pés. Entretanto, os dados coletados para análise experimental eram compostos por, no máximo, três sílabas. Em decorrência disso, nas palavras analisadas (todas paroxítonas), a cabeça do pé sempre coincidiu com a sílaba tônica, como exemplificado em (7). Para tentarmos preencher esta lacuna, utilizamos, então, dados de fala espontânea ${ }^{11}$, nos quais pudemos selecionar os dados em (8). Nessa representação, as sílabas são associadas como $\mathrm{F}$ (forte) ou $f$ (fraca) e, cada par de nós de um nível mais baixo projeta um nó no nível imediatamente superior (Magalhães e Battisti 2017). Essa projeção segue uma relação binária de proeminência, e, por isso, observamos um pé forte $(\mathrm{F})$ e um pé fraco $(f)$ projetados em $\mathrm{F}$, que corresponde ao acento primário de uma palavra projetada em $\mathrm{W}$.

(8)

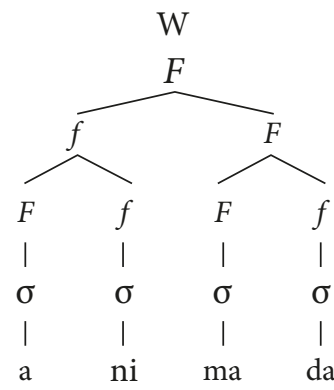

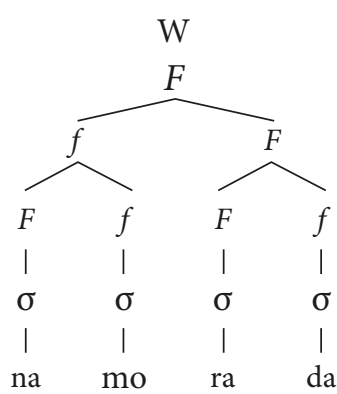

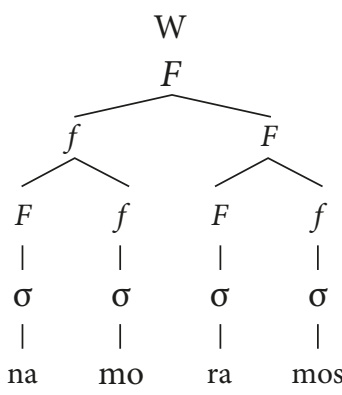

Em (8.a) e (8.b), a vogal baixa [a] do pé mais à esquerda, no caso (ani) e (namo), embora estivesse na cabeça do pé (F), não foi nasalizada. Esse comportamento, por um lado, não elimina a hipótese da importância do pé como domínio de aplicação do processo, posto que a nasalização heterossilábica é opcional mesmo quando a vogal-alvo, além de ser a cabeça do pé, porta o acento lexical $(F)$. Além disso, também não é capaz de alterar a generalização inicial que previa que a nasalidade heterossilábica não se aplicaria a sílabas átonas. Por outro lado, em itens como namoramos, em (8.c), [a] de (namo) foi nasalizada, indicando, a princípio, a possível importância do domínio e proeminência do pé para a nasalização heterossilábica, pois o processo foi aplicado independentemente de a sílaba ser átona. ${ }^{12} \mathrm{O}$ mesmo foi verificado em palavras como analisar e camarada. No entanto, algumas ressalvas precisam ser feitas em relação ao resultado extraído de (8c). Em primeiro lugar, os dados em (8) são produzidos por falantes diferentes dos informantes

11 Foi analisado um corpus formado por entrevistas sociolinguísticas, com duração de 60 minutos cada, coletadas em STP. Trabalhamos com três entrevistas para o PST e três entrevistas para o PP, todas realizadas com informantes que tinham entre 18 e 52 anos. No total, trabalhamos com 27 ocorrências das palavras: analisar; animada; namorada; namoramos; camarada.

12 F1 de [a] nasalizada em (namo) de namoramos: $246 \mathrm{~Hz}$; F1 de [a] oral em (namo) de namorada: $442 \mathrm{~Hz}$. Valores extraídos de um mesmo informante. 
do experimento e, por isso, a diferença entre os falantes, bem como entre a metodologia de coleta podem encobrir influências de variáveis externas e independentes sobre o resultado. Assim, sugerimos a hipótese de que o pé possa ser um domínio relevante para o processo de nasalização heterossilábica, com a ressalva, porém, de que são necessários testes experimentais e a ampliação do corpus de fala espontânea para sua confirmação empírica.

O processo de nasalização heterossilábica é, portanto, caracterizado pelo espraiamento do traço [+nasal] da consoante nasal [m] ou [n] para a raiz do segmento vocálico anterior, ocorrendo sob as seguintes condições:

(i) a vogal-alvo porte o acento lexical da palavra; e

(ii) a vogal-alvo esteja contígua à consoante nasal, isto é, não haja uma consoante em posição de coda entre os segmentos envolvidos.

A princípio, o domínio do pé parece ser importante para a aplicação do processo, sendo o espalhamento da nasalidade possível para a vogal baixa localizada na cabeça do pé, quando a sílaba seguinte é iniciada por uma consoante nasal. Tais características distinguiriam o PST e o PP do $\mathrm{PB}$ e do $\mathrm{PE}$, variedades nas quais a nasalização pode ocorrer independentemente da tonicidade ou do domínio do pé binário, já que é visível na primeira sílaba átona de itens como camada, em que a vogal da sílaba inicial [ka] pode ser nasalizada a despeito de estar fora do pé troqueu. No quadro 5, comparamos, de forma geral, o processo de nasalização heterossilábica nas diferentes variedades do português tratadas neste artigo.

\begin{tabular}{|ll|}
\hline $\boldsymbol{P S T / P P}$ & $\boldsymbol{P B} / \boldsymbol{P E}$ \\
\hline Engatilhado por onset [+nasal] & Engatilhado por onset [+nasal] \\
\hline Espraiamento Regressivo & Espraiamento Regressivo \\
\hline Vogal-alvo contígua ao onset [+nasal] & Vogal-alvo contígua ao onset [+nasal] \\
\hline Opcional em sílabas tônicas & Obrigatória em sílabas tônicas \\
\hline Bloqueado em sílabas átonas que não sejam $\left(^{*}\right)$ & - \\
\hline Pode estar condicionada ao domínio do pé & Ocorre independentemente do domínio do pé \\
\hline
\end{tabular}

Quadro 6: Comparação da nasalização heterossilábica entre variedades do português.

A análise dos dados com diferentes vogais, sucedidas por uma sílaba com onset nasal em posição tônica ('CV.NV) ou em posição átona ( $\mathrm{CV}$.'NV), demonstra que a nasalidade heterossilábica pode ser opcional, tanto no PST, como no PP. Essa opcionalidade do processo difere do fenômeno no $\mathrm{PB}$ e no $\mathrm{PE}$, já que nessas variedades da língua portuguesa, o processo de nasalização por onset é obrigatório em sílabas tônicas. Logo, dentro da sequência $\left({ }^{\prime} \mathrm{CV}_{1} \cdot \mathrm{NV}_{2}\right), \mathrm{V}_{1}$ sempre será nasaliza- 
da (Miguel 2006; Moraes e Wetzels 1992). Sendo assim, podemos pressupor que a não aplicação do processo é um traço característico ao PST e ao PP. A origem dessa especificidade pode estar associada ao contato linguístico com o santome e o lung’le, línguas nas quais o fenômeno de nasalização heterossilábica é opcional em qualquer contexto.

Diante de tais aproximações entre o PST e o PP e duas das línguas autóctones de STP, reconhecemos o contato como elemento promotor da variação e da mudança linguística, como também sugerimos uma influência do processo de aquisição do português a partir de uma interlíngua pelos falantes de santome e de lung'Ie, corroborando Gonçalves (2010), Christofoletti (2013) e Balduino (2018). Historicamente, o português se tornou a língua majoritária em STP no último quartel do século XX, tendo convivido com as línguas autóctones da maioria da população nos últimos cinquenta anos (Araujo 2020). Portanto, o português foi adquirido como uma segunda língua, inicialmente, até ter se estabelecido como L1. Dessa forma, algumas transferências estruturais podem ter ocorrido nesse processo de transmissão irregular do português (Lucchesi e Baxter 2009). Apesar de, no mesmo período, ser verificada a democratização do ensino em São Tomé (Araujo 2020), o que possibilitou o acesso à escolarização de parte da população, é preciso ressaltar que este acesso (i) não era homogêneo à sociedade do arquipélago, estando concentrado, sobretudo, nos centros urbanos que, à época, eram menores em relação aos centros urbanos atuais; (ii) dizia respeito, apenas, aos quatro primeiros anos de escolarização e, por isso, não havia um acesso prolongado ao ensino formal da língua portuguesa; (iii) as crianças já eram falantes das línguas autóctones como L1 e a aprendizagem do português dava-se, inicialmente, como L2. Sendo assim, não houve, antes de 1975, uma formalização do acesso à língua portuguesa que pudesse limitar a transmissão linguística irregular no arquipélago. Dessa forma, a migração de trabalhadores falantes de variedades de português adquiridas como L2 e seus descendentes das unidades agroindustriais (roças ou fazendas) para os centros urbanos, associada ao estabelecimento do português como língua oficial e à escolarização ampla promovida pelo Governo de 1975 foram alguns dos fatores que promoveram a massificação da língua portuguesa (Araujo 2020).

\section{Considerações finais}

A partir da análise de itens lexicais em contexto de nasalização heterossilábica no PST e no PP, observamos que a nasalidade engatilhada por um onset nasal contíguo a uma vogal é de caráter opcional e que não foi constatada, nos dados, nasalização heterossilábica em contexto pretônico. Embora este fato, por um lado, não descarte a possibilidade da realização do processo nessa língua, por outro, demonstra que sua ocorrência não é muito comum. Além disso, também concluímos que a natureza da nasalização heterossilábica é distinta da natureza da nasalidade vocálica tautossilábica, ocasionada a partir do espraiamento do traço [+nasal] de uma coda silábica. Em geral, as vogais nasalizadas por meio do onset silábico, independentemente do gesto articulatório suplementar para a produção da nasalidade, são mais curtas em relação à vogal nasal e à vogal oral e nunca demonstram o apêndice nasal. Isso ocorre, pois o espraiamento da nasalidade do onset nasal $[\mathrm{m}]$ e $[\mathrm{n}]$ é associado diretamente à /a/, o qual, através da assimilação da nasalidade, ativa o traço [+nasal], e não promove reestruturação silábica. Dessa forma, a consoante nasal respon- 
sável por engatilhar o espraiamento da nasalidade não é elidida segmentalmente e, por isso, esta é plenamente realizada e associada a uma unidade temporal dentro da sílaba. O mesmo ocorre com [a], o qual é associado a uma unidade temporal correspondente ao nó de raiz vocálico ao qual pertence, diferente das vogais nasalizadas por coda, que, em termos fonéticos, equivalem à duração da vogal e da consoante nasal em coda elidida. Portanto, o apagamento de /N/ em coda ocasiona uma reestruturação silábica do padrão CV para o padrão CVC sem, entretanto, perder a unidade temporal fonológica da sílaba, a qual é compensada pelo alongamento de [ $[\tilde{\mathfrak{e}}]$.

Mesmo que os resultados reforcem a opcionalidade do processo de nasalização heterossilábica em contexto tônico nas variedades de STP e sua distinção do processo de nasalização tautossilábica, seria necessário ampliar o estudo, para que possamos ter uma visão mais abrangente do comportamento da língua. A esse respeito, o contraste com dados obtidos com o auxílio de frases-veículos com dados retirados da fala espontânea pode fortalecer a hipótese de que a nasalidade heterossilábica, mesmo em tônicas, é opcional, bem como promove um campo mais amplo para analisarmos a não aplicabilidade do processo em pretônicas. Por fim, tendo em vista os dados e a interpretação dada à nasalização a partir do onset para o santome (Bandeira 2017) e para o lung'Ie (Agostinho 2015, 2016), entendemos, que, no que diz respeito a este fenômeno, o PST e o PP aproximam-se das línguas autóctones, distanciam-se do PE e do PB e firmam-se como variedades singulares.

\section{Referências bibliográficas}

Agostinho, A. L. (2015). Fonologia e Método Pedagógico do lung'Ie. (PhD). Universidade de São Paulo, São Paulo. . (2016). Fonologia do Lung'Ie. Muenchen: LINCOM.

Agostinho, A. L.; Balduino, A. M.; \& Araujo, G. A. de. (2020). Nasalization processes in Lung'Ie. Alfa, 64, 1, 1-27. doi: https://doi.org/10.1590/1981-5794-e11574

Agostinho, A. L.; \& Hyman, L. M. (2021). Word Prosody in Lung'Ie: One System or Two? Probus, 33, 1, 57-93. <https://doi.org/10.1515/PRBS-2021-0002>

Albano, E. (2017). Fonologia de Laboratório. In D. d. Hora, \& C. L. Matzenauer (Eds.), Fonologia, fonologias (pp. 169-182). São Paulo: Contexto.

Araujo, G. A. de. (2020). Há uma política linguística para o português em São Tomé e Príncipe? In S. Souza, \& F. C. Olmo (Eds.), Línguas em português. A Lusofonia numa visão Crítica (vol. 1) (pp. 173-197). Porto: University of Porto Press.

Araujo, G. A. de.; \& Balduino, A. M. (2019). Nasalização Vocálica no Português Urbano de São Tomé e Príncipe. Diacrítica, 33, 2, 41-68. doi: https://doi.org/10.21814/diacritica.256

Balduino, A. M. (2018). A nasalidade no português de São Tomé e Príncipe. (Mestrado). Universidade de São Paulo, São Paulo.

Bandeira, M. (2017). Reconstrução fonológica e lexical do protocrioulo do Golfo da Guiné. (PhD). Universidade de São Paulo, São Paulo.

Barbosa, P.; \& Madureira, S. (2015). Manual de Fonética Acústica e Experimental. São Paulo: Cortez Editora. 
Baxter, A. N. (2002). Semicreolization? The restructured Portuguese of the Tongas of São Tomé, a consequence of L1 acquisition in a special contact situation. Journal of Portuguese Linguistics, 1, 1, 7-39. doi: http://doi.org/10.5334/jpl.47

. (2018). O Português dos Tongas de São Tomé. In M. S. D. Oliveira, \& G. A. de. Araujo (Eds.), O Português na África Atlântica. São Paulo: Humanitas/FAPESP.

Bisol, L. (1992). O acento e o pé métrico binário. Cadernos de Estudos Lingüísticos, 22, 69-80. doi: https://doi. org/10.20396/cel.v22i 0.8636897

- (1994). O acento e o pé métrico. Letras de Hoje, 29, 4, 25-36.

Boersma, P.; \& Weenick, D. (2015). Praat: doing phonetics by computer (Version 5.4.08 ). < http://www.praat.org>

Bonvini, E. (2008). Línguas africanas e português falado no Brasil. In J. L. Fiorin, \& M. Petter (Eds.), África no Brasil: a formação da língua portuguesa. São Paulo: Contexto.

Câmara Jr., J. M. (1970). Estrutura da Língua Portuguesa. Petrópolis: Vozes.

Christofoletti, A. (2013). Ditongos no português de São Tomé e Príncipe. (Mestrado). Universidade de São Paulo, São Paulo.

Ewen, J. C.; \& Hulst, H. v. d. (2001). The phonological structure of words: an introduction. Cambridge: Cambridge University Press.

Figueiredo, C. (2010). A concordância plural variável no sintagma nominal do português reestruturado da comunidade de Almoxarife, São Tomé. Português. Universidade de Macau. Macau.

- (2014). Português de Almoxarife, São Tomé: sentenças relativas com relativizadores ku e com. Filologia e Linguística Portuguesa, 16, 2, 277-309. doi: http://dx.doi.org/10.11606/issn.2176-9419. v16i2p277-309

Gonçalves, R. (2010). Propriedade de Subcategorização verbal no português de S. Tomé. (Mestrado). Universidade de Lisboa, Lisboa.

INE. (2012). Instituto Nacional de Estatística: São Tomé e Príncipe em Números.

Kent, R.; \& Read, C. (2015). Análise Acústica da Fala. São Paulo: Cortez Editora.

Lao, S. (2020). Variação da Nasalização Regressiva Heterossilábica em Portugal Continental. (Master). Universidade de Lisboa,

Lao, S.; Rodrigues, C.; \& Bressos, F. (2020). Nasalização regressiva heterossilábica (NRH) da vogal /a/ acentuada em PE. Revista da Associação Portuguesa de Linguística, 11, 7, 295-314.

Lucchesi, D.; \& Baxter, A. N. (2009). A transmissão linguística irregular. In O português afro-brasileiro (pp. 101-124). Salvador: EDUFBA.

Magalhães, J.; \& Battisti, E. (2017). Fonologia Métrica. In D. d. Hora, \& C. L. Matzenauer (Eds.), Fonologia, fonologias (pp. 169-182). São Paulo: Contexto.

Mateus, M. H.; \& D’Andrade, E. (2000). The Phonology of Portuguese. Oxford: Oxford University Press.

Medeiros, B. (2007). Vogais nasais do português brasileiro: reflexões preliminares de uma revista. Revista Letras, 72, 165-188.

Miguel, M. A. C. (2006). Vogais nasais e nasalizadas: uma falsa questão? Paper presented at the I Encontro de Estudos Dialectológicos.

Moraes, J. (2003). Produção e percepção das vogais nasais. In B. Abaurre (Ed.), Gramática do português culto falado no Brasil: a construção fonológica da palavra (vol. 2) (pp. 92-112). São Paulo: Contexto.

Moraes, J.; \& Wetzels, W. L. (1992). Sobre a duração dos segmentos vocálicos nasais e nasalizados em português: um exercício de fonologia experimental. Cadernos de Estudos Lingüísticos, 23, 153-166. doi: https:// doi.org/10.20396/cel.v23i0.8636851 
Ohala, J. (1995). Experimental Phonology. In J. Goldsmith (Ed.), A Handbook of Phonological Theory. Oxford: Blackwell.

Souza, L. C. d. S.; \& Pacheco, V. (2012). Uma análise acústica das vogais orais, nasais e nasalizadas do dialeto de Vitória da Conquista, Bahia. Signum: Estudos Linguísticos, 15, 401-432.

Wetzels, W. L. (1997). The lexical representation of nasality in Brazilian Portuguese. Probus, 9, 2, 1-34. doi: https://doi.org/10.1515/prbs.1997.9.2.203 
